\title{
Changes in the vascular cell adhesion molecule-1, intercellular adhesion molecule-1 and c-reactive protein following administration of aqueous extract of piper sarmentosum on experimental rabbits fed with cholesterol diet
}

\author{
Adel A Amran', Zaiton Zakaria ${ }^{1 *}$, Faizah Othman², Srijit Das², Hesham M Al-Mekhlafi ${ }^{3}$, Nor-Anita MM Nordin ${ }^{1}$
}

\begin{abstract}
Background: Inflammation process plays an important role in the development of atherosclerosis. Hypercholesterolemia is one of the major risk factors for atherosclerosis. The present study aimed to evaluate the effect of aqueous extract of Piper sarmentosum (P.s) on inflammatory markers like vascular cell adhesion molecule-1 (VCAM-1), intercellular adhesion molecule-1 (ICAM-1), and C-reactive protein (CRP).

Methods: Forty two male New Zealand white rabbits were divided equally into seven groups; (i) C- control group fed normal rabbit chow (ii) $\mathrm{CH}$ - cholesterol diet (1\%cholesterol) (iii) X1- 1\% cholesterol with water extract of P.s (62.5 mg/kg) (iv) X2- 1\% cholesterol with water extract of P.s (125 mg/kg (v) X3- 1\% cholesterol with water extract of P.S (250 mg/kg) (vi) X4- 1\% cholesterol with water extract of P.S $(500 \mathrm{mg} / \mathrm{kg}$ ) and (vii) SMV group fed with $1 \%$ cholesterol supplemented with simvistatin drug $(1.2 \mathrm{mg} / \mathrm{kg})$. All animals were treated for 10 weeks. Blood serum was taken for observing the inflammatory markers at the beginning and end of the experiment.

Results: Rabbits fed with 1\% cholesterol diet $(\mathrm{CH})$ showed significant increase in the level of VCAM-1, ICAM-1 and CRP compared to the $C$ group. The levels of VCAM-1, ICAM-1 and CRP in the $1 \%$ cholesterol group and supplemented with P.s $(500 \mathrm{mg} / \mathrm{kg})$ were significantly reduced compared to the cholesterol group. Similar results were also reported with simvistatin group.
\end{abstract}

Conclusion: These results suggest that the supplementation of Piper sarmentosum extract could inhibit inflammatory markers which in turn could prevent atherosclerosis.

\section{Background}

Inflammation is a major pathophysiological mechanism in atherosclerosis [1]. Histopathologically, atherosclerosis is characterized by a thickening of the vascular wall due to lipid accumulation and infiltration of macrophages and lymphocytes $[2,3]$. Many evidences have indicated the presence of many cell adhesion molecules and growth factors in atherosclerosis. Other reports have stressed that there are interactions between the adhesion

\footnotetext{
* Correspondence: adel_emran@hotmail.com

'Department of Physiology, Faculty of Medicine, Universiti Kebangsaan

Malaysia, Jalan Raja Muda Abdul Aziz, Kuala Lumpur 50300, Malaysia

Full list of author information is available at the end of the article
}

molecules and growth factors in inflammatory responses. Researches have shown that the development of atherosclerosis is caused by a complex interaction between reactive oxygen species, lipids, endothelium, circulation and tissue inflammatory cells, platelets and vascular smooth muscle cells and was not simply due to the accumulation of lipids $[4,5]$.

Hypercholesterolemia is one of the most important risk factors for atherosclerosis and related occlusive vascular disease [6]. Recent observations suggest that the endothelium's dysfunction and inflammation cause not only the initial stage of the atherosclerotic process but also atherosclerotic plaque development.

\section{C) Biomed Central}


Vascular cell adhesion molecule VCAM-1 and intercellular adhesion molecule ICAM-1 are endothelial adhesion molecules of the Ig gene superfamily that may participate in atherogenesis by promoting monocyte accumulation in the arterial intima [7]. Elevated levels of inflammatory markers, especially CRP, are associated with an increased risk of cardiovascular disease $[1,8,9]$. Serum CRP stimulates endothelial cell expression of (ICAM-1) and (VCAM-1) [10]. The ICAM-1 and VCAM-1 are important factors in the development of atherosclerosis and may play an important role in promoting the local inflammation within the atherosclerotic plaque [11]. Cellular adhesion molecules like ICAM-1 and VCAM-1 are involved in the rolling, adhesion and extravasation of monocytes and T-lymphocytes [12-14]. This migration is one of the earliest events in the atherosclerotic process in addition to its later contribution to the chronic inflammatory process. Pathological studies of human atherosclerosis have shown increased expression of CAMs located in endothelial cells. Increased levels of soluble (s) forms of CAMs in circulating blood have been found in a number of conditions with an inflammatory component $[15,16]$. Various studies have showed there are many inflammatory markers that can predict cardiovascular events, including cell adhesion molecules, cytokines, chemokines, acute phase reactants such as fibrinogen, serum amyloid A and CRP. Additionally, CRP which has recently emerged as one of the most important inflammatory mediators can directly participate in the pathogenesis of atherosclerosis by activating endothelial cells and promoting the inflammatory component of atherosclerosis $[2,3]$. CRP plays a crucial role in the pathogenesis of the vascular inflammatory process which is abrogated by simvastatin therapy. In this study we focus on the effect of natural antioxidant on inflammatory markers, ICAM-1, VCAM-1 and CRP. The results of the present study may help in the prevention and treatment of atherosclerosis. Research in herbal medicine can provide an alternative solution to health problems.

Piper sarmentosum belongs to the family Piperaceae. In different parts of the world, P.s has been used traditionally to cure many diseases [17]. Phytochemically, the plant contains constituents like alkaloids (amide, flavonoids, pyrones) [18] and it has also been reported to possess pharmacological properties like antituberculosis [19] anticancer [20], anti-angiogenic [21], anti-diabetic [22], antimalarial [23], antioxidant [24], neuromuscular blocker [25] and antiamoebic [26]. Previous study has indicated that aqueous extract of Piper sarmentosum may improve endothelial function by promoting $\mathrm{NO}$ production in HUVECs [27] and our previous study indicated that Ps can be reduce atherosclerosis lesion [28]. Piper sarmentosum has flavonoids compounds which are widely distributed in plants which have been reported to have antioxidant, free radical scavenging abilities and antiinflammatory effect [29]. The active extract of P. sarmentosum contains natural antioxidants like Naringenin (75.7\%), Hesperitin (91.7\%), Taxifolin/Dihydroquercitin (90.9\%) and Quercetin (98.1\%) which have high superoxide scavenging action [24].. The antioxidant activities of phynolic compounds like flavonoid which have anti-inflammatory action by inhibiting IL6 and TNF and inhibits the aggregation and adhesion of platelets in the blood [30]. It has been also shown that flavonoids reduce LDL oxidation, which is an important step in atherogenesis [31].

\section{Materials and methods}

\section{Animals and experimental protocol}

This study was approved by the Animal Ethics Committee, Universiti Kebangsaan Malaysia. Forty two male New Zealand White rabbits average body weight between $1.8 \pm 2 \mathrm{~kg}$ were purchased from East Asia Rabbit Corporation Sdn. Bhd. Malaysia. The animals were housed separately in cages in an air-conditioned room with a 12-h light/dark cycle. All animals had free access to water. The rabbits were divided randomly into seven groups; control group $(\mathrm{C} ; \mathrm{n}=6)$ was fed the rabbit chow, cholesterol group $(\mathrm{CH} ; \mathrm{n}=6)$ was fed the similar diet enriched with $1 \%$ cholesterol, experimental groups $(\mathrm{X} 1 ; \mathrm{n}=6, \mathrm{X} 2 ; \mathrm{n}=6, \mathrm{X} 3 ; \mathrm{n}=6$ and $\mathrm{X} 4 ; \mathrm{n}=6)$, were fed with similar diet enriched with $1 \%$ cholesterol plus different doses of water extract of P.s $(62.5,125,250$ and $500 \mathrm{mg} / \mathrm{kg} /$ day) respectively. The simvistatin group (Smv; $\mathrm{n}=6$ ) was fed with the standard diet mixed with $1 \%$ cholesterol plus simvistatin drug $(1.2 \mathrm{mg} / \mathrm{kg} /$ day, Merck, NJ) [32]. The experiment was continued till 10 weeks. The blood sample was taken at the beginning of the study and the end of the study via the marginal ear vein. At the end of 10 weeks, the animals were fasted overnight and sacrificed by intravenous injection of pentobarbital (Nembutal, Abbott Laboratories, North Chicago, IL, $50 \mathrm{mg} / \mathrm{kg}$ body weight) and the abdominal aortic tissue was collected for histological studies.

\section{Preparation of the aqueous extract of P.s extract}

The aqueous extract of P.s leaves were extracted in the laboratory of Furley Marketing Sdn, Bhd, Malaysia. The freeze dried powdered extract was prepared after that in the laboratory of Faculty of Pharmacy, Universiti Kebangsaan Malaysia, where the powdered extract was stored in dark bottles and kept in $4^{\circ} \mathrm{C}$ until used. The administration dose powder was mixed with $5 \mathrm{ml}$ of water to dissolve and given to rabbits as oral dose by special needle.

\section{High cholesterol diet}

Cholesterol powder was purchased from (Sigma Chemical Co., St. Louis, USA), it was mixed with the rabbit 
chow pellet ( $1 \%$ cholesterol, w/w, in food pellet). For each $200 \mathrm{~g}$ of grounded rabbit chow pellet, $2 \mathrm{~g}$ of cholesterol was added and mixed with a $34 \mathrm{ml}$ of chloroform where cholesterol was dissolved in 99.9\% chloroform and then mixed with grounded rabbit chow pellet. Chloroform was evaporated by exposing the diets as a thin layer at $50^{\circ} \mathrm{C}$ in oven [33].

\section{Diphenylpicrylhydrazyl (DPPH) for estimating antioxidant activity}

1, 1-Diphenyl-2-picryl-hydrazyl (DPPH) was purchased from Sigma (USA). Ascorbic acid was purchased from Sigma USA. To measure antioxidant activity, the (DPPH), radical-scavenging assay was carried according to previous method [34,35] with slight modification. Briefly the DPPH $500 \mu \mathrm{m}$ stock solution was prepared by adding $19.716 \mathrm{mg}$ of DPPH to $100 \mathrm{ml}$ of methanol and mixed until the purple colour appeared. The stock solution of vitamin $\mathrm{C}$ was used as positive control and sample were prepared $(1000 \mathrm{mg} / \mathrm{ml})$ with different dilution $(500,200,100,50,25,12.5$ and $0 \mathrm{mg} / \mathrm{ml})$. The DPPH was mixed with the sample and vitamin $C$ and all the tubes were left in room temperature for 30 mins in the dark. The colour was read at the absorbance at 515 $\mathrm{nm}$ against blank samples and the calculations of the scavenging effect (\%) are as follows:

$$
\text { Scavenging effect }(\%)=\left(1-\frac{\text { A sample }- \text { A sample blank }}{\text { A control }}\right) \times 100
$$

$\mathrm{A}_{\text {control }}=\mathrm{Abs}$ of DPPH solution without sample

$\mathrm{A}_{\text {sample }}=\mathrm{DPPH}$ solution sample

$\mathrm{A}_{\text {sample blank }}=$ sample without DPPH

The data is commonly reported as $\mathrm{IC}_{50}$, which is the concentration of antioxidant required for $50 \%$ scavenging of DPPH radicals in the specified time period

\section{Evaluation of Plasma Circulatory Markers (VCAM-1) and (sICAM-1)}

The level concentrations of circulating Rabbit Soluble Intercellular Adhesion Molecule-1 (sICAM-1) and soluble vascular cell adhesion molecule 1(VCAM-1) were measured using Rabbit Enzyme-Linked Immunosorbent Assay (ELISA) and a commercially available kit (Uscn Life Science \& technology company, USA) according to the manufacturer's instructions. Values of samples were calculated from a standard curve generated from standards of known concentration. Absorbance at $450 \mathrm{~nm}$ was determined using VERSA microplate reader (USA).

Measurement of Plasma Rabbit High-Sensitive $C$ - reactive protein by Enzyme-Linked Immunosorbent Assay (ELISA) The quantification CRP level in plasma was determined using rabbit high-sensitive CRP ELISA kits from Kamiya
Biomedical (Seattle, WA). The results was calibrated by the the software calculation that was provided with the VERSA microplate reader (USA) and compared to the calibration standard curve.

\section{Statistical analysis}

Statistical analysis was carried out using the SPSS statistical package version 18 (SPSS Inc. USA). Distribution of data was examined by Kolmogrov-Smirnov test and found to be normal. Paired t-test was used to compare between 0 time and end time in the same group and ANOVA test was used to compare between the groups.

\section{Results}

(DPPH) for estimating antioxidant activity

The result showed the DPPH radical-scavenging activity of the water extract has high antioxidant activities (Figure 1) indicated by the increase in the concentration of the sample. The antioxidant activities of the IC 50 scavenger activity of water extract was $27.12 \mathrm{mg} / \mathrm{ml}$.

\section{Plasma Circulatory Markers (VCAM-1) and (sICAM-1) and CRP}

There was no significant difference in ICAM-1, VCAM1 and CRP levels between 0 time and end time of experiment in the control group $(C)$. In the atherosclerosis group there were significant increase between 0 times and end time for all ICAM-1, VCAM-1 and CRP. A similar finding was reported with the X1 group $(62.5$ $\mathrm{mg} / \mathrm{kg}$ ). In groups X2 and X3 (125 and $250 \mathrm{mg} / \mathrm{kg}$ ), there were also significant differences between 0 time and end time. In groups X4 $(500 \mathrm{mg} / \mathrm{kg})$ and simvastatin, there was no significant difference between the 0 times and the end time of experiment. There was also significant increase in atherosclerotic and X1 groups as compared to control group. There were statistically significant reductions in the levels of ICAM-1, VCAM-1 and CRP at the end of treatment with water extract in group $500 \mathrm{mg} / \mathrm{kg}$ compared to atherosclerosis group. Similarly simvistatin group also showed significant reductions in the levels of ICAM-1, VCAM-1 and CRP compared to atherosclerosis group (Figure 2, 3, 4 and 5)

\section{Discussion}

The present study showed that the water extract of P.s has high antioxidant activities and free radical-scavenging activity. The effect of antioxidants on DPPH radical scavenging may be due to their hydrogen donating ability. The antioxidant properties of P.s were demonstrated in previous reports [24]. In general, some antioxidants can prevent atherosclerosis by protecting LDL from oxidation and are also associated with an anti-hypercholesterolemic effect [36,37]. Several epidemiological studies 


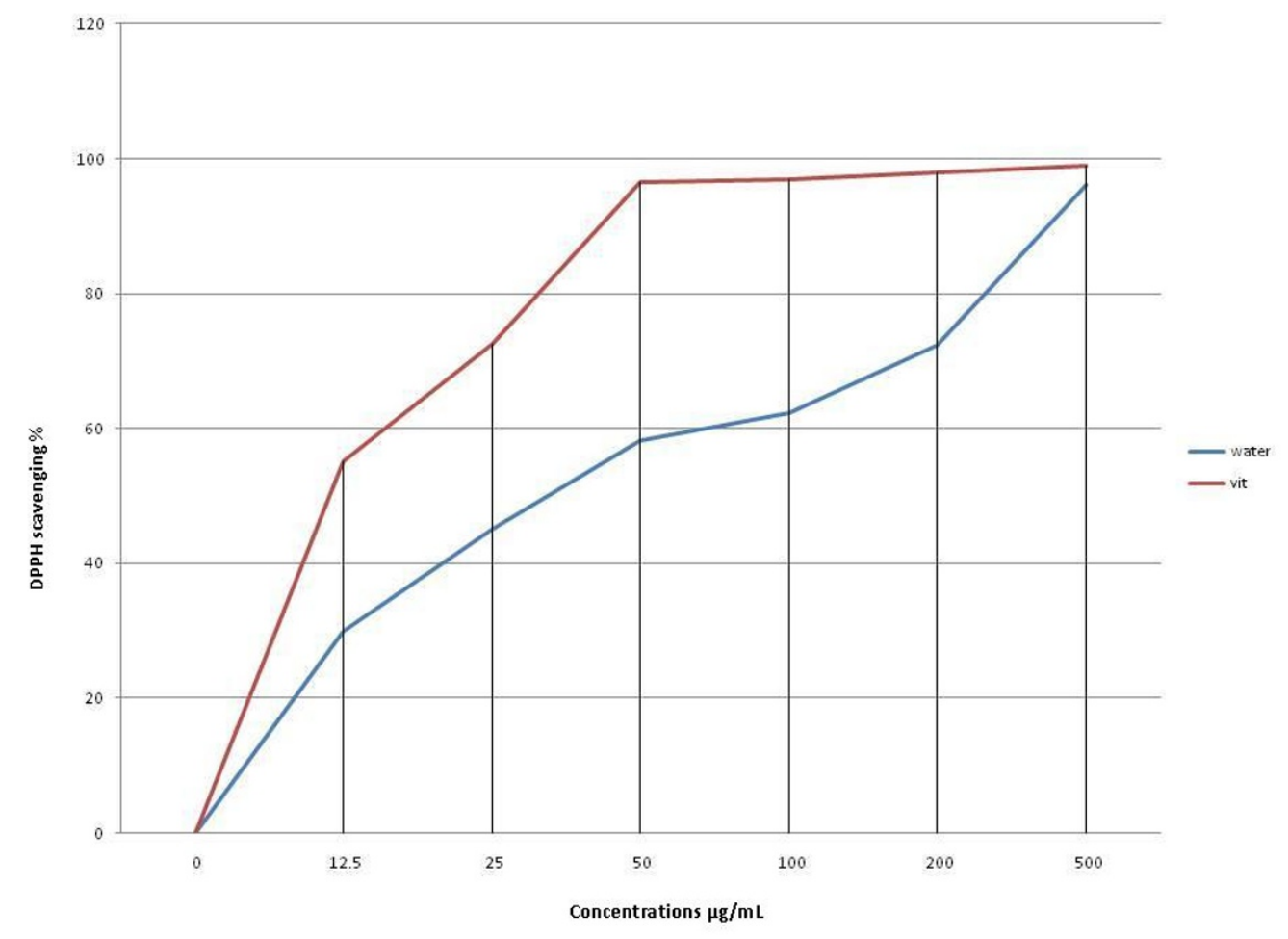

Figure 1 DPPH radical scavenging activity of water extract of Ps. Observation as $I C_{50}$.

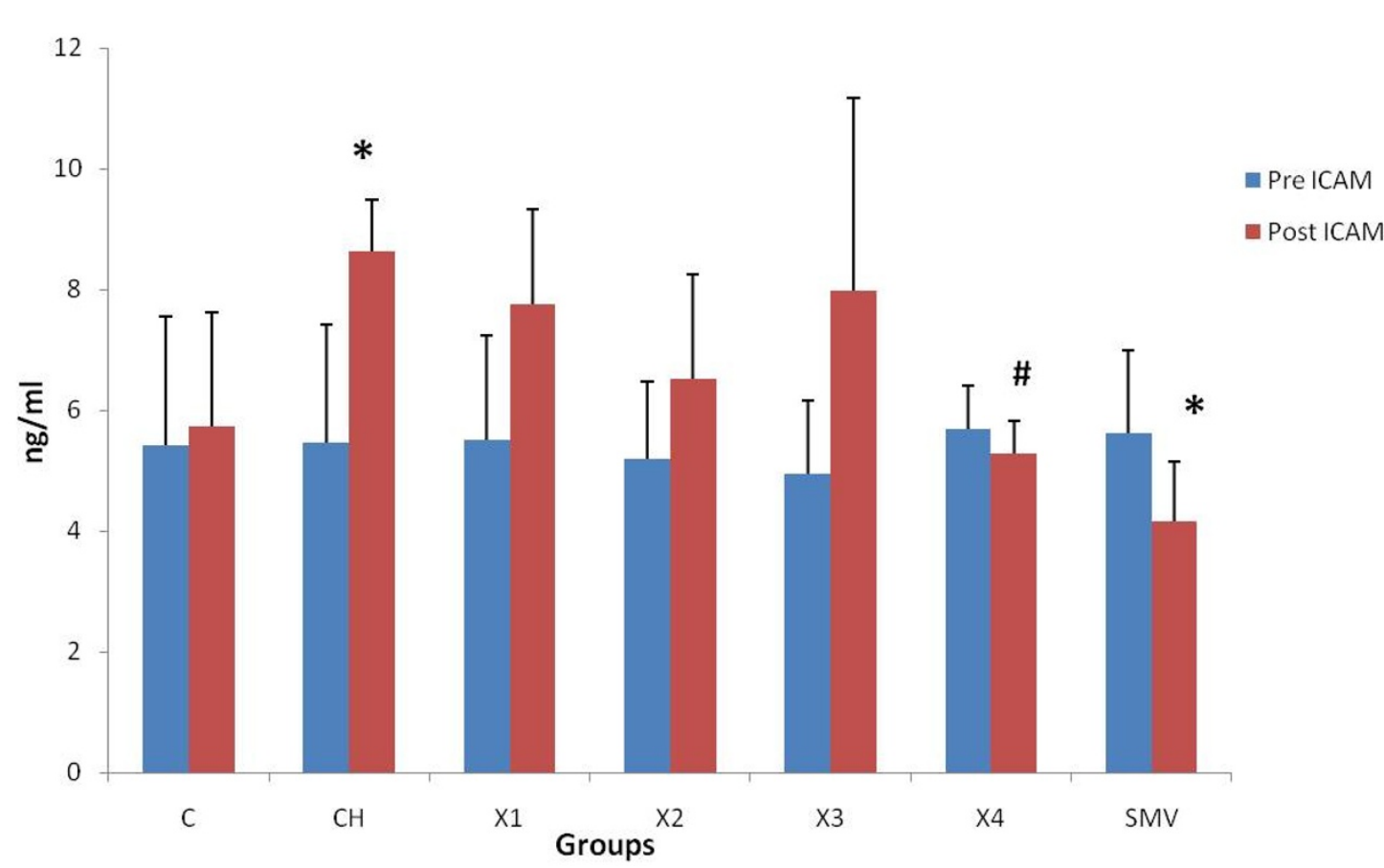

Figure 2 Determination level of ICAM in the pretreatment and post treatment in the different groups. ${ }^{*}<<0.05$ as compare to control group. ${ }^{\# P}<0.05$ as compare to atherosclerosis group. 


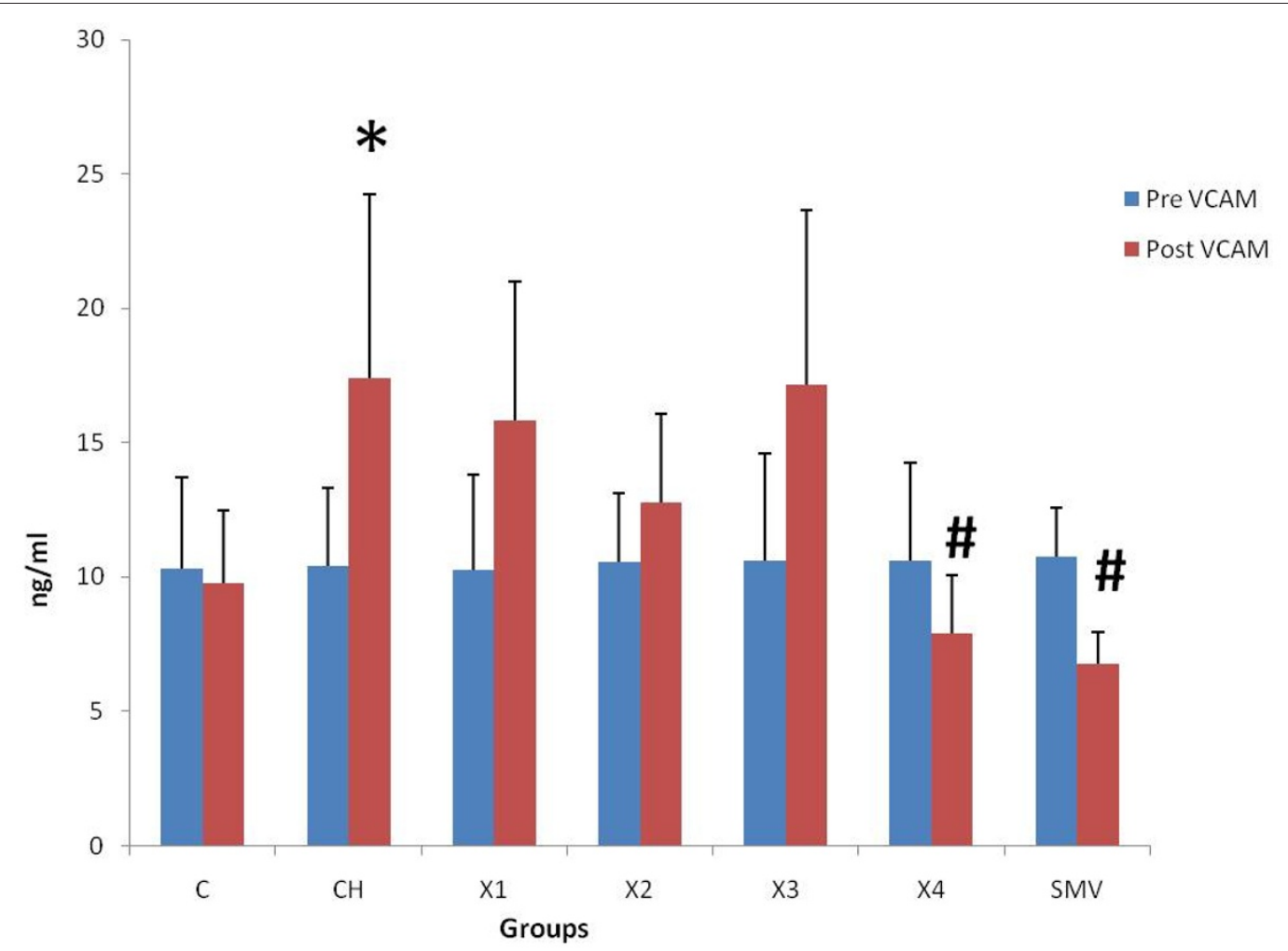

Figure 3 Determination level of VCAM in the pretreatment and post treatment in the different groups. ${ }^{*} P<0.05$ as compare to control group." $\mathrm{P}<0.05$ against atherosclerosis group.

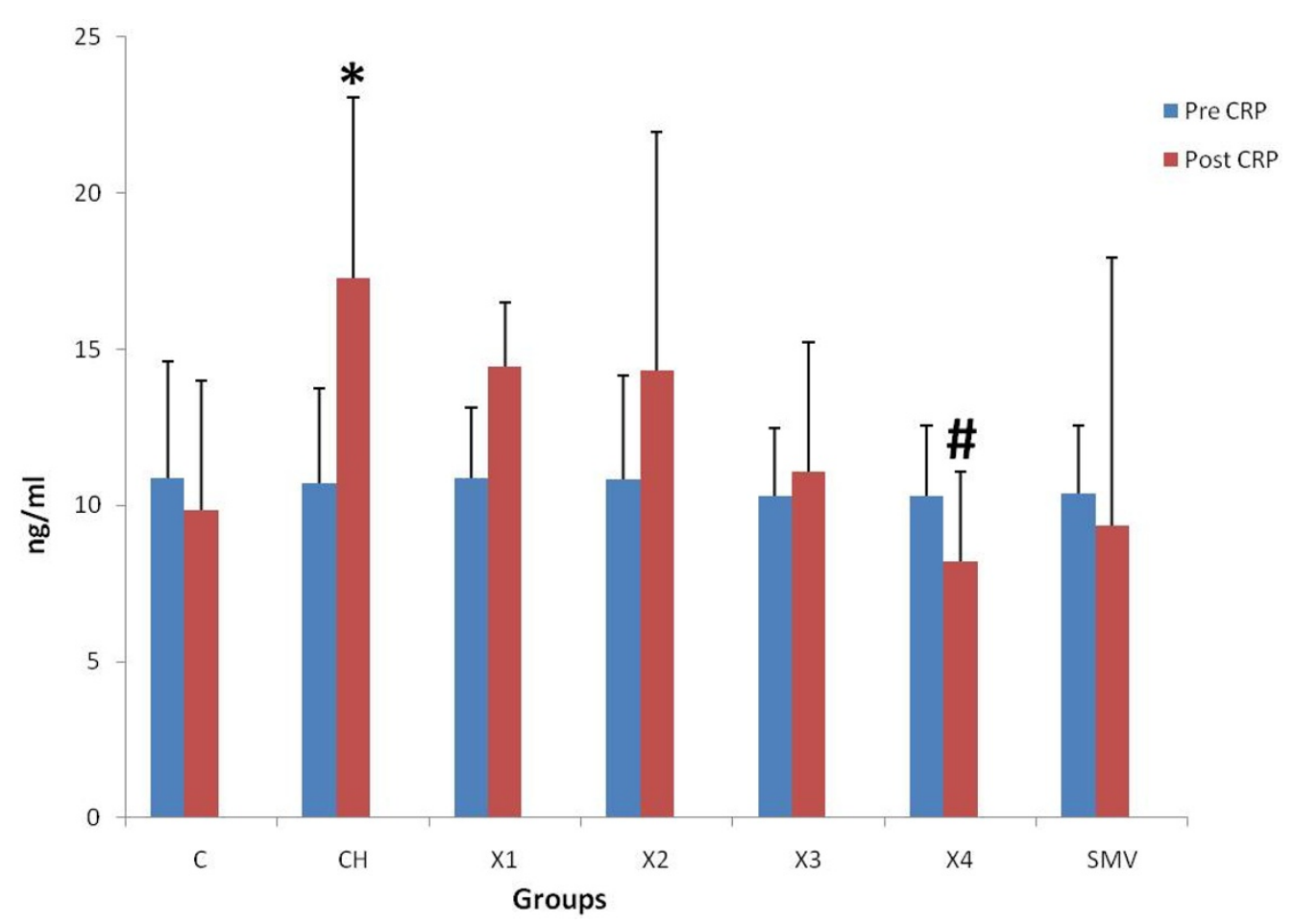

Figure 4 Determination level of CRP in the pretreatment and post treatment in the different groups. ${ }^{*} \mathrm{P}<0.05$ as compare to control group. ${ }^{~} \mathrm{P}<0.05$ against atherosclerosis group. 


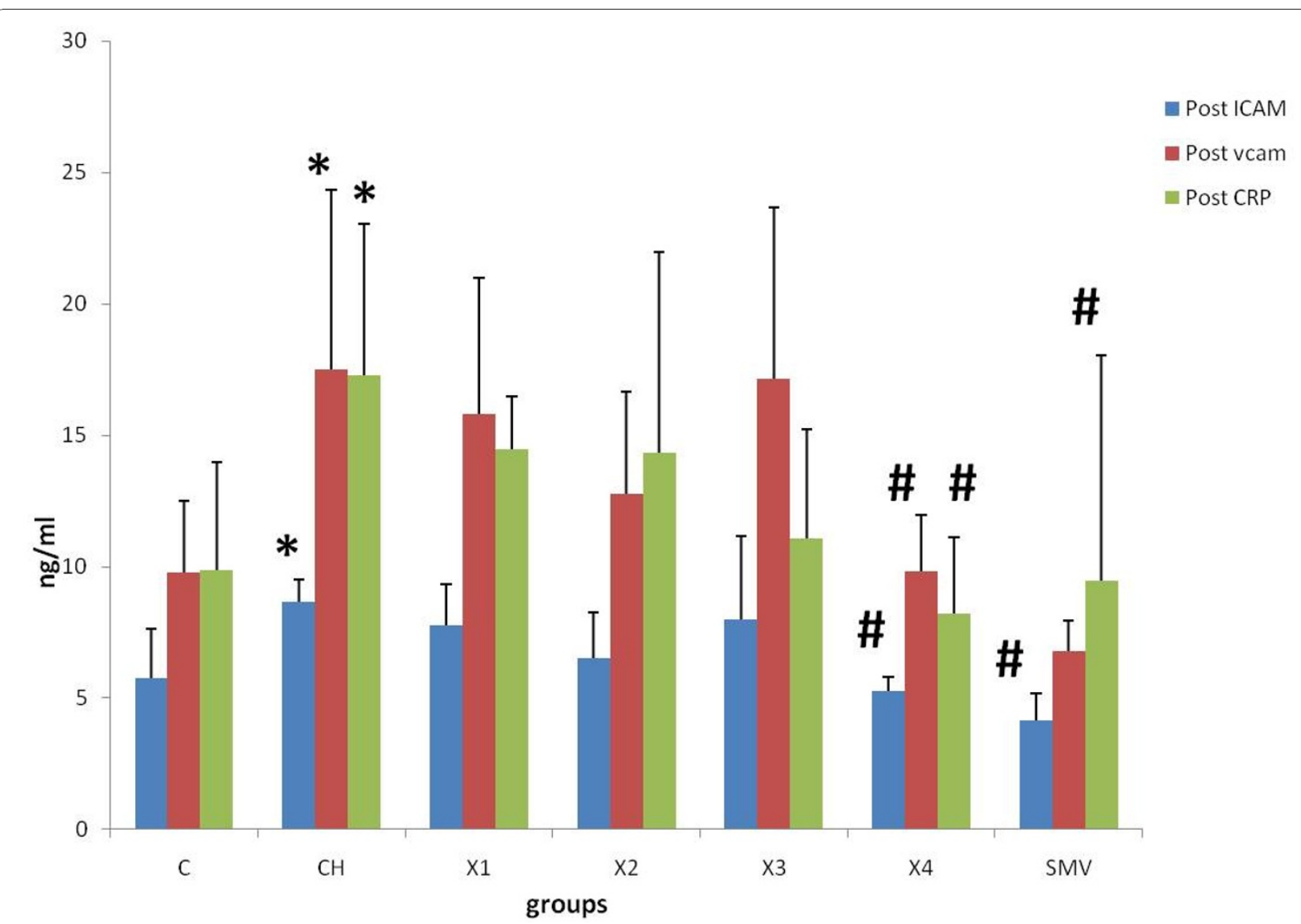

Figure 5 Effect of ICAM, VCAM and CRP between the different groups. ${ }^{* P}<0.05$ as compare to control group. ${ }^{\#} P<0.05$ against atherosclerosis group.

have reported that increased dietary intake of natural antioxidants correlates with reduced coronary heart disease. Food rich in antioxidants plays an essential role in the prevention of cardiovascular diseases [38,39]. The extract compounds of P.s contains active compound like Naringenin(75.7\%), Hesperitin (91.7\%), Taxifolin/Dihydroquercitin(90.9\%) and Quercetin (98.1\%) which have high superoxide scavenging action [24]. However, there are no research reports on the effect of P.s on inflammatory markers in rabbits given cholesterol diet. The consumption of a cholesterol enriched diet increases the degree of lipid peroxidation, which is also one of the early processes involved in atherosclerosis.

After 10 weeks of treatment with water extract of P.s together with high cholesterol diet, the present study showed that ICAM, VCAM-1 and CRP levels were significantly decreased compared to rabbits given a high cholesterol diet. This study showed that treatment with this extract at the dose $500 \mathrm{mg} / \mathrm{kg}$ and simvistatin group can decrease the rise in ICAM-1, VCAM-1 and CRP. The mechanism of P.s in reducing the inflammatory markers is still unknown but this result suggests that this extract may have an antioxidant effect on inflammatory markers in rabbits given cholesterol diet. A previous study showed significant decreased levels of CRP in dyslipidemic patients with coronary artery disease treated with simvastatin $20 \mathrm{mg}$ per day for 4 months [40]. Another study indicated that CRPmediated inflammation is inhibited by simvastatin [39]. Previous studies showed that the elevated levels of CRP are associated with an increased risk of cardiac events [42-44]. We observed a significant increase in circulating VCAM-1, ICAM-1 levels when fed the cholesterol diet in rabbits. Increased levels of cell adhesion molecules in blood from patients with atherosclerosis have been observed in previous studies $[45,46]$, supporting the theory that soluble inflammatory markers are involved in the pathophysiology of atherosclerosis. Prospective epidemiological studies have shown increased cardiovacsular risk associated with increased basal levels of soluble ICAM-1, VCAM-1, P-selectin, and E-selectin [47-50].

Atherosclerosis, which is a chronic inflammatory disease of arteries, is characterized by a thickening of the 
vascular wall and an infiltration of macrophages and lymphocytes. In animals with diet-induced or genetically determined hyperlipidemia, the earliest morphological changes in arteries include focal adherence of mononuclear leukocytes to the endothelium and accumulation of monocyte-derived foam cells in the intima [51,52].

The mechanisms that link diet-induced hyperlipidemia in the evolution of cellular changes in the arterial wall still remain poorly understood. VCAM-1 expression might conceivably result from macrophage accumulation because activated macrophages can produce many of the cytokines known to stimulate endothelial VCAM-1 expression [53]. Oxidative stress induced inflammatory responses cause damage to the vasculature and may play an important role in the development of many diseases including atherosclerosis [54]. Activation of endothelial cells by oxidants may lead to a wide range of functional changes such as an increased expression of VCAM-1, ICAM-1, and E-selectin, and the production of chemokines, such as monocyte chemoattractant peptide-1. The resulting attraction and transendothelial migration of monocytes are believed to be critical to the initiation and progression of atherosclerosis [55]. The protective effect of antioxidant is still not clear but it may serve as a protective function by preventing the oxidation of LDL.

\section{Conclusion}

This study suggests that hypercholesterolemic atherosclerosis is associated with an increase in inflammatory markers and that Piper sarmentosum is effective in reducing the inflammation which is important in the process of atherosclerosis.

\section{Abbreviations \\ (P.s): Piper sarmentosum; (C): control group; (CH): Atherogenic group; ( $\mathrm{x1)}$ : $1 \%$ cholesterol together with water extracts of P.S with doses $62.5 \mathrm{mg} / \mathrm{kg}$ group: (X2): $1 \%$ cholesterol together with water extracts of P.S with doses $125 \mathrm{mg} /$ kg;(X3): 1\% cholesterol together with water extracts of P.S with doses 250 $\mathrm{mg} / \mathrm{kg} ;(\mathrm{X} 4)$ : $1 \%$ cholesterol together with water extracts of P.S with doses $500 \mathrm{mg} / \mathrm{kg}$;(Smv): 1\% cholesterol supplemented with simvistatin drug 1.2 mg/kg; (HO-1):heme oxygenase-1; LDL: Low Density Lipoprotein; CVD: Cardiovascular D(VCAM-1): vascular cell adhesion molecule-1;(ICAM-1): intercellular adhesion molecule-1;(CRP);(CAMs): cellular adhesion molecule-1; (DPPH): 1,1-Diphenyl-2-picryl-hydrazyl.}

\section{Acknowledgements}

The research was supported by grant from the science fund grant from the Ministry of Science, Technology and Innovation. The authors wished to thank Universiti Kebangsaan Malaysia for this study. The authors would also like to thank Furley Marketing Sdn.Bhd. Malaysia for the plant extraction, Mrs Zanariyah for her technical assistance.

\section{Author details}

'Department of Physiology, Faculty of Medicine, Universiti Kebangsaan Malaysia, Jalan Raja Muda Abdul Aziz, Kuala Lumpur 50300, Malaysia. ${ }^{2}$ Department of Anatomy, Faculty of Medicine, Universiti Kebangsaan Malaysia, Jalan Raja Muda Abdul Aziz, Kuala Lumpur 50300, Malaysia.
${ }^{3}$ Department of Parasitology, Faculty of Medicine, University of Malaya, Kuala Lumpur 50603, Malaysia.

\section{Authors' contributions}

ZZ was involved in supervising the project, and revising the manuscript critically for important intellectual content. AA carried out all aspects of experiments, design and data analysis, and drafted the manuscript and revising it critically for important intellectual content. FO was involved in interpreting the results and revising it critically for important intellectual content. SD was involved in histological interpretation of results, design, grammars, technical assistance in preparing the manuscript. Hm for statistical analysis and design and NMN were involved in the extraction of Piper sarmentosum and revising the manuscript critically for important intellectual content. All authors have read and approved the final manuscript.

\section{Competing interests}

The authors declare that they have no competing interests.

Received: 29 November 2010 Accepted: 9 January 2011

Published: 9 January 2011

\section{References}

1. Biasucci L, Colizzi C, Rizzello V, Vitrella G, Crea F, Liuzzo G: Role of inflammation in the pathogenesis of unstable coronary artery diseases. Scand J Clin Lab Invest 2000, 59:12-22.

2. Verma S, Buchanan MR, Anderson TJ: Endothelial function testing as a biomarker of vascular disease. Circulation 2003, 108:2054-2059.

3. Szmitko PE, Wang CH, Weisel RD, de Almeida JR, Anderson TJ, Verma S: New markers of inflammation and endothelial cell activation: part I. Circulation 2003, 108:1917-23

4. Orford JL, Selwyn AP, Ganz P, Popma JJ, Rogers C: The comparative pathobiology of atherosclerosis and restenosis. Am J Cardiol 2000, 86:6H-11H.

5. Kher N, Marsh JD: Pathobiology of atherosclerosis-a brief review. Semin Thromb Hemost 2004, 30:665-672.

6. Ross R, Harker L: Hyperlipidemia and atherosclerosis: chronic hyperlipidemia initiates and maintains lesions by endothelial cell desquamation and lipid accumulation. Science 1976, 193:1094-1100.

7. Myron I Cybulsky, Kaeko liyama, Hongmei Li, Suning Zhu, Mian Chen, Motoi liyama, Vannessa Davis, Jose-Carlos Gutierrez-Ramos, Philip W Connelly, David S Milstone: A major role for VCAM-1, but not ICAM-1, in early atherosclerosis. J Clin Invest 2001, 107:1255-1262.

8. Ridke $\mathrm{P}$ M, Rifai N, Rose L, Buring JE, Cook NR: Comparison of C- reactive protein and low-density lipoprotein cholesterol levels in the prediction of first cardiovascular events. New England Journal of Medicine 2003, 347:1557-65

9. Ridker PM, Rifai N, Pfeffer M, Sacks F, Lepage S, Braunwald E: Elevation of tumor necrosis factor-alpha and increased risk of recurrent coronary events after myocardial infraction. Circulation 2000, 101:2149-2155.

10. Pasceri V, Willerson J, Yeh E: Direct proinflammatory effect of C-reactive protein on human endothelial cells. Circulation 2000, 102:2165-2178.

11. Torzewski M, Rist C, Mortensen R, Zwaka TP, Bienek M, Waltenberger J, Koenig W, Schmitz G, Hombach V, Torzewski J: C-reactive protein in the arterial intima. Role of C-reactive protein receptor-dependent monocyte recruitment in atherogenesis. Arteriosc Thromb Vasc Biol 2000, 20:2094-2109.

12. Yangsoo J, Lincoff M, Plow EF, Topol EJ: Cell adhesion molecules in coronary artery disease. J Am Coll Cardiol 1994, 24:1591-1601.

13. Carlos BT, Kovach N, Schwartz B, Rosa M, Newman B, Wayner E, Benjamin C, Osborn L, Lobb R, Harlan J: Human monocytes bind to two cytokineinduced adhesive ligands on cultured human endothelial cells: endothelial-leukocyte adhesion molecule-1 and vascular cell adhesion molecule-1. Blood 1991, 77:2266-2271.

14. Graber N, Gopal TV, Wilson D, Beall LD, Polte T, Newman W: T cells bind to cytokine-activated endothelial cells via a novel, inducible sialoglycoprotein and endothelial leukocyte adhesion molecule-1. J Immunol 1990, 145:819-830.

15. Gearing AJH, Newman W: Circulating adhesion molecules in disease. Immunol Today 1993, 14:506-512. 
16. Ballantyne CM, Mainolfi EA, Young JB, Windsor NT, Cocanougher B, Lawrence EC, Pollack MS, Entman ML, Rothlein R: Relationship of increased levels of circulating intercellular adhesion molecule 1 after heart transplantation to rejection: human leucocyte antigen mismatch and survival. J Heart Lung Transplant 1994, 13:597-603.

17. Saralamp P, Chuakul W, Temsiririrkkul R, Clayton T: Medicinal plants in Thailand. Bangkok, Amarin 1996, 1:151.

18. Tutiwachwuttikul P, Phansa P, Pootaeng-on Y, Tylor WC: Chemical constituents of the roots Piper sarmentosum. Chem Pharm Bull 2006, 54(suppl 2):149-151.

19. Hussain K, Ismail Z, Sadikun A, Ibrahim P: Analysis of proteins, polysaccharides, glycosaponins contents of Piper sarmentosum Roxb. and anti-TB evaluation for bio- enhancing/interation effects of leaf extracts with isonazid(INH). Natural Product Radiance 2008, 7(Suppl 5):204-208.

20. Shahrul HZA, Wan Haifa HWO, Zaidah ZA, Muhd FS, Sahidan S, Rohaya MAW: Intrinsic anticarcinogenic effects of Piper sarmentosum ethanolic extract on a human hepatoma cell line. Cancer Cell Int 2009, 9:6.

21. Hussain K, Ismail Z, Sadikun A, Ibrahim P, Malik A: in vitro antiagiogenesis activity of standardized extract of Piper sarmentosum Roxb. J Ris Kim 2008, 1:146-150

22. Penchom P, Suwan ST, Rungravi T, Hirosh W, Jeevan KP, Shigetoshi K: Hypoglycemic effect of the water extract of Piper sarmentosum in rats. J Ethnopharmacol 1998, 60:27-32.

23. Najib Nik A, Rehman N, Furuta T, Kojima S, Takane K, Ali MM: Antimalarial activity of extracts of Malaysian medicinal plants. J Ethnopharmacol 1999, 64:249-254.

24. Vimala S, Mohd IA, Abdull RA, Rohana S: Natural Antioxidants: Piper sarmentosum (Kadok) and Morinda elliptica. Mal J Nutr 2003, 9(suppl 1):41-51.

25. Ridititid W, Rattanaporm W, Thaina P, Chittrakaran S, Sunbhanich M: Neuromuscul ar blocking activity of methanolic extract of Piper sarmentosum leaves in the rat phrenic nerve hemi diaphragm preparation. J Ethnopharmacol 1998, 61:135-142

26. Sawangjiaroen N, Sawangjiaroen K, Poonpanang P: Effect of Piper longum fruit, Piper sarmentosum root and Quercus infectoria nut gall on caecal amoebiasis in mic. J Ethnopharmacol 2004, 91:357-360.

27. Azizah U, Zaiton Z, Chua KH, Nor Anita MMN: Piper sarmentosum increases nitric oxide production in oxidative stress: a study on human umbilical vein endothelial cells. Clinics 2010, 65(7):709-714.

28. Adel Amran, Zaiton Z*, Faizah O, Srijit D, Santhana RL, Nor-Anita MMN: Aqueous extract of Piper sarmentosum decreases atherosclerotic lesions in high cholesterolemic experimental rabbits. Lipids in Health and Disease 2010, 9:44.

29. Alan LM: Antioxidant flavonoids structure, function and clinical using. Alternative Medicine Review 1996, 1:103-111.

30. Seong CC, Hyo SK, Tae SJ, Song HB, Young BP: Naringin Has an Antiatherogenic Effect With the Inhibition of Intercellular Adhesion Molecule-1 in Hypercholesterolemic Rabbits. J Cardiovasc Pharmacol 2001, 38:947-955.

31. De Whalley CV, Rankin SM, Hoult JR, Jessup WDS: Flavonoids inhibit the antioxidative modification of low density lipoproteins. Biochem Pharmacol 1990, 39:1743-1749.

32. Tsung ML, Mei SL, Tsai FC, Nen CC: Effect of simvastatin on left ventricular mass in hypercholestrolemic rabbits. Am J Physiol Heart Circ Physiol 2005, 288:1352-1358.

33. Julie HC, Johnny LE, Nicole JS, Gordon RC: Molecular basis by which garlic suppresses atherosclerosis. Journal of Nutrition 2001, 131:1006-1009.

34. Duan X J, Zhang W W, Li X M, Wang BG: Evaluation of antioxidant property of extract and fractions obtained from a red alga, Polysiphonia urceolata. Food Chemistry 2006, 95:37-43.

35. Gordon MH, Paiva-Martins F, Almeida M: Antioxidant activity of hydroxytyrosol acetate compared with that of other olive oil polyphenols. J Agric Food Chem 2001, 49:2480-2485.

36. Chen MF, Hsu HC, Liau CS, Lee YT: The role of Vitamin E on the antiatherosclerotic effect of fish oil in diet-induced hypercholesterolemic rabbits. Prostaglandings other Lipid Mediators 1999, 57:99-111.

37. Freyschuss A, Al-Schurbaji A, Bj̈orkhem I, Babiker A, Diczfalusy U, Berglund L, Henriksson P: On the antiatherogenic effect of the antioxidant BHT in cholesterol-fed rabbits: inverse relation between serum triglycerides and atheromatous lesions. Biochim Biophys Acta 2001, 1534:129-138.

38. Gerber M, Boutron-Rault MC, Hereberg S, Riboli E, Scalbert A, Siess MH: Food and cancer: state of the art about the protective effect of fruits and vegetables. Bull Cancer 2002, 89:293-312.

39. Di Matteo V, Esposito E: Biochemical and therapeutic effects of antioxidants in the treatment of Alzheimer's disease, Parkinson's disease and amyotrophicl ateralsclerosis. Curr Drug Targets: CNS Neurol Disord 2003, 2:95-107.

40. Strandberg TE, Vanhanen H, Tikkanen MJ: Effects of statins on C-reactive protein in patients with coronary artery disease. Lancet 1999, 353:118-119.

41. Hon-Kan Yip a, Cheuk-Kwan Sun b, Li-Teh Chang c, Chiung-Jen Wu a, Sarah Chua a, Morgan Fu: Strong suppression of high-sensitivity reactive protein level and its mediated pro-atherosclerotic effects with simvastatin: In vivo and in vitro studies. Int J Cardio/ 2007, 121(3):253-260.

42. Koenig W, Sund M, Frohlich M, Fischer HG, Löwel H, Döring A, Hutchinson WL, Pepys MB: C-reactive protein, a sensitive marker of inflammation, predicts future risk of coronary heart disease in initially healthy middle-aged men: results from the MONICA Augsburg Cohort Study, 1984 to 1992. Circulation 1999, 99:237-242.

43. Mueller C, Buettner HJ, Hodgson JM, Marsch S, Perruchoud AP, Roskamm H, Neumann FJ: Inflammation and longterm mortality after non-ST elevation acute coronary syndrome treated with a very early invasive strategy in 1042 consecutive patients. Circulation 2002, 105:1412-1415.

44. Pai JK, Pischon T, Ma J, Manson JE, Hankinson SE, Joshipura K, Curhan GC, Rifai N, Cannuscio CC, Stampfer MJ, Rimm EB: Inflammatory makers and the risk of coronary heart disease in men and women. $N$ Engl J Med 2004, 351:2599-2610.

45. Hackman A, Abe Y, Insull Jr W, Pownall H, Smith L, Dunn K, Gotto AM Jr, Ballantyne CM: Levels of soluble cell adhesion molecules in patients with dyslipidemia. Circulation 1996, 93:1334-1338.

46. Schumacher A, Seljeflot I, Sommervoll L, Christiansen B, Otterstad JE, Arnesen $\mathrm{H}$ : Increased levels of vascular inflammation in patients with coronary heart disease. Scand J Clin Lab Invest 2002, 62:59-68.

47. Blankenberg S, Rupprecht HJ, Bickel C, Peetz D, Hafner G, Tiret L, Meyer J: Circulating cell adhesion molecules and death in patients with coronary artery disease. Circulation 2001, 104:1336-1342.

48. Ridker PM, Hennekens CH, Roitman-Johnson B, Stampfer MJ, Allen J: Plasma concentration of soluble intercellular adhesion molecule 1 and risk of future myocardial infarction in apparently healthy men. Lancet 1998, 351:88-92

49. Hwang SJ, Ballantyne CM, Sharrett AR, Smith LC, Davis CE, Gotto AM Jr Boerwinkle E: Circulating adhesion molecules VCAM-1, ICAM-1, and Eselectin in carotid atherosclerosis and incident coronary heart disease cases. The Atherosclerosis Risk in Communities (ARIC) study. Circulation 1997, 96:4219-25

50. Ridker PM, Buring JE, Rifai N: Soluble P-selectin and the risk of future cardiovascular events. Circulation 2001, 103:491-495.

51. Klurfeld DM: Identification of foam cells in human atherosclerotic lesions as macrophages using monoclonal antibodies. Arch Pathol Lab Med 1985, 109:445-449.

52. Rogers KA, Hoover RL, Castellott JJ, Robinson JM, Karnovsky MJ: Dietary cholesterol-induced changed in macrophage characteristics relationship to atherosclerosis. Am J Pathol 1986, 125:284-291.

53. Libby $P$, Hansson GK: Involvement of the immune system in human atherogenesis: Current knowledge and unanswered questions. Lab Invest 1999, 64:5-15

54. Babior BM: Oxidants from phagocytes: agents of defense and destruction. Blood 1984, 64:959-966

55. Ross R: Atherosclerosis: an inflammatory disease. New Engl J Med 1999 340:115-126.

doi:10.1186/1476-511X-10-2

Cite this article as: Amran et al: Changes in the vascular cell adhesion molecule-1, intercellular adhesion molecule- 1 and c-reactive protein following administration of aqueous extract of piper sarmentosum on experimental rabbits fed with cholesterol diet. Lipids in Health and Disease 2011 10:2. 